\title{
THE SUTTONS AND THE BUSINESS OF INOCULATION
}

\author{
by
}

\author{
DAVID VAN ZWANENBERG*
}

\section{SUMMARY}

THE SUTTONS, an eighteenth-century family of Suffolk surgeons consisting of Robert Sutton and six of his sons, were largely responsible for promoting the practice of inoculation for smallpox from an occasional medical procedure to a widespread business venture. Their fame and fortune increased in the second half of that century as inoculation became more popular. Jenner's publication of his method of vaccination in $1798^{1}$ led to a decline in the use of inoculation and it was finally made illegal in $1840 .{ }^{2}$ Possibly because their method of trying to prevent smallpox was superseded by vaccination, the reputation of the Suttons declined to such an extent that some commentators have regarded them as quacks, and their method of inoculation as both valueless and dangerous.

Although there have been a number of short accounts about the Suttons, it is believed that this is the first attempt to trace their progress from contemporary sources and to evaluate their methods. Some of the previous accounts are based on that published in the book Lettsom, ${ }^{3}$ and were apparently derived from family traditions which contemporary sources have shown to be inaccurate.

EARLY HISTORY OF INOCULATION IN ENGLAND ${ }^{4}$

The inoculation of smallpox had been practised in Turkey and elsewhere "in the East" before the eighteenth century. Several reports of its use reached the Royal Society of London during the early 1700 s. The method became more widely known after it had been described in a letter to Mrs. Chiswell from Lady Mary Wortley Montagu, who was in Turkey in 1717. After her return to London, Lady Mary had her small daughter inoculated by Mr. Charles Maitland in April 1721. In May 1721 Maitland also inoculated Dr. Keith's son, and went on to inoculate six condemned criminals in Newgate in 1722. In April of that year the king's surgeon, Claude Amyand, inoculated Princess Amelia aged eleven and Princess Caroline aged nine. Following these events, the procedure gained some degree of acceptance both by the medical

*David Van Zwanenberg, D.M., M.A., D.C.H., D.P.H., Consultant Physician, The Ipswich Hospital, St. Helen's Wing, Foxhall Road, Ipswich IP3 8LY.

\footnotetext{
${ }^{1}$ Edward Jenner, An inquiry into the causes and effects of variolae vaccinae, a disease discovered in some of the western counties of England, particularly Gloucestershire, and known by the name of cowpox, London, Sampson Low, 1798.

'Vaccination Act, 1840.

J. J. Abraham, Lettsom. His life, times, friends and descendants, London, Heinemann, 1933.

- Early history in England, taken from C. W. Dixon, Smallpox, London, J. \& A. Churchill, 1962.
} 


\section{David Van Zwanenberg}

profession and the general public, but in the next few years it was not often used. Nettleton inoculated sixty-one persons in Yorkshire in 1722, which was the largest series achieved for many years. ${ }^{5}$ By 1728 only 897 inoculations had been recorded in England and Scotland with seventeen deaths. ${ }^{\circ}$

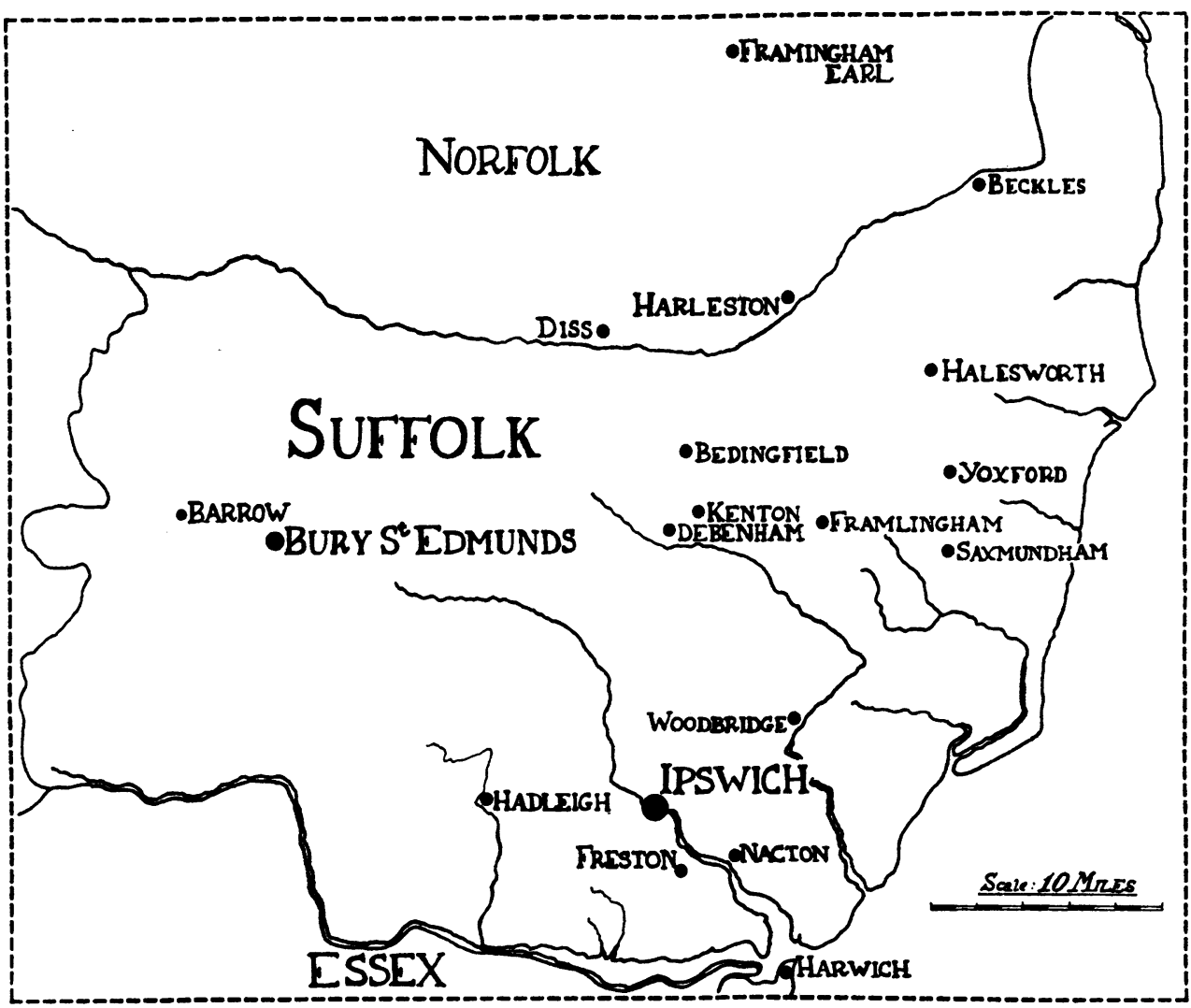

Map showing the situation of the towns jand villages of Norfolk and Suffolk which are referred to in the text.

EARLY HISTORY OF INOCULATION IN SUFFOLK

The earliest reference to inoculation in Suffolk is found in a letter by Dr. William Beeston from Ipswich in 1724:" "The practice of inoculation in this town has so enflamed the angry passions and stirred up the bitter zeale of the bigotted High Churchmen and Dissenters to such a degree that they sentence to damnation all that are in anyway connected with it ....". The next reference occurs when Dr. Beeston himself inoculated Robert Warner, a student of Pembroke Hall, at Woodbridge in $1729 .^{8}$ This inoculation, which was successful, was presumably reported

- T. Nettleton, An account of the success of inoculating the smallpox, London, 1722.

- C. P. Monty, 'Smallpox, scourge of mankind', Hist. of Med., winter 1971, p. 25.

7 Quoted by Dixon, op. cit., note 4 above-original reference not traced.

- Ipswich Journal, 25 October 1724. 


\section{The Suttons and the business of inoculation}

because it was an unusual event.

In 1733 Dr. D. Hartley, a physician in Bury St. Edmunds, wrote a pamphlet ${ }^{9}$ advocating that inoculation should be introduced as it could be spread through the town much faster than natural smallpox. Basing his argument on Nettleton's experience, he assessed the hazard from inoculated smallpox as one chance in fifty whereas the mortality in natural smallpox was four times greater. There is, however, no evidence that inoculation was used extensively in Bury St. Edmunds at that time.

In 1742 John Rodbard, a surgical apprentice in Woodbridge, inoculated himself and used the same technique on his patients thereafter. ${ }^{10}$ It is not known where he learned the technique since his master, James Lynn, was not inoculated until ten years later. ${ }^{11}$ No references to inoculation in or around Woodbridge have been found between Dr. Beeston's case in 1729 and John Rodbard's self-inoculation in 1742. Dr. Beeston had died in 1732, and therefore could not have instructed Rodbard. ${ }^{12}$ On completing his apprenticeship in 1745 , John Rodbard moved to Debenham where he practised as a surgeon.

\section{ROBERT SUTTON}

Robert Sutton, the first member of the family to practise inoculation, was the son of a gentleman. ${ }^{13}$ The family lived at Kenton, a small village in central Suffolk about three miles from Debenham, and Robert was baptized there on 12 February 1707.14 In 1726 he was apprenticed to John Turner, a surgeon in Debenham; ${ }^{15}$ in due course he completed his training and practised in and around Kenton. ${ }^{16}$ The exact date when he started to practise on his own is not known. He was still living in Debenham at the time of his marriage in $1731,{ }^{17}$ but was registered as having a licence to practise surgery at Kenton in $1735 .{ }^{18 *}$

Robert Sutton must have known John Rodbard well: not only were they near neighbours but they were both involved in a local controversy in 1751 when Rodbard accused another local surgeon, Thomas Debenham, of mismanaging a case of extrauterine pregnancy; Robert Sutton supported Debenham. ${ }^{19}$ Nevertheless, in 1756 Robert Sutton invited John Rodbard to inoculate his eldest son Robert ( $j r$.) (baptized in 1732). ${ }^{20}$ Young Robert suffered a severe attack of smallpox. Possibly it was this

\footnotetext{
-D. Hartley, Some reasons why the practice of inoculation ought to be introduced into the town of Bury at present, Bury St. Edmunds, 1733.

10 Ipswich Journal, 14 February 1767. Account written by Rodbard.

11 Ibid., 30 May 1752.

12 Monumental inscription, Bentley Church, Suffolk. Dr. Beeston died on 4 December 1732.

13 Ipswich Journal, 15 and 22 March 1755.

14 Kenton Parish Register, East Suffolk Record Office, Ipswich.

${ }^{16}$ Apprenticeship Book, Board of Inland Revenue, IR.17.36. Public Record Office.

16 Ipswich Journal, 16 and 23 September 1749.

17 Aldeburgh Parish Register. East Suffolk Record Office, Ipswich.

18 Norwich Diocesan Register of Surgeons, Midwives, and Schoolmasters. Microfilm in East Suffolk Record Office, Ipswich.

19 Ipswich Journal, 22 June 1752.

${ }^{20}$ Kenton Parish Register, op. cit., note 14 above.
}

*This does not necessarily mean that he began practising at this date, as surgeons seem to have been registered in groups according to the area where they lived. Sutton's master, John Turner, was also registered in 1735. 


\section{David Van Zwanenberg}

experience which persuaded his father to improve the technique of inoculation.

In April 1757 Robert Sutton (sr.) advertised that he had "hired a large house for the reception of persons who are disposed to be inoculated by him for the smallpox, terms for inoculation, boarded, nursed, tea, wine, Fish and Fowl $£ 7 / 7 /-$ per month, $£ 5 / 5 /$ - for farmers, $10 / 6$ for non boarders ...."21 This was the first advertisement for inoculation in the Ipswich Journal. It was repeated in several issues and followed by a series of similar advertisements but with added information. By October, Sutton had "two commodious houses for persons to be inoculated" and claimed "remarkable success with this method in the spring." ${ }^{22}$ In April 1758 it was described as "The Art of the Inoculation that was carried on by Robert Sutton .... with the greatest success". ${ }^{23}$ Later in that year he had built an entirely new house for this purpose, and also attended for inoculation at Diss, Framlingham, Harleston, and Halesworth on market days. ${ }^{24} \mathrm{He}$ announced in February 1759 that he was continuing "the practice of inoculation with the greatest success, never having lost one patient or had one so bad as to be blind with it". ${ }^{25}$ By September he had three houses, one for reception, one for nursing, and one for the airing of patients. He now claimed "never having had one bad symptom"..26

A year later the business had become too large for him to manage alone, so he made arrangements with surgeons in Woodbridge, Ipswich, Diss, Yoxford, and Saxmundham to inoculate patients using the Suttonian method. During this year Sutton himself had inoculated "upwards of 200 , having never met with one accident". 27 In August 1760 the first advertisement by a rival inoculator appeared in the Ipswich Journal, ${ }^{28}$ so Robert Sutton had gained a three-year advantage in the business. By the end of 1761, although Robert Sutton "continued the art of inoculation with his usual success", he had to admit to "one accident out of the many hundreds he had under his care". His usual fee was now $£ 55 \mathrm{~s}$. Od., but "for the benefit of the lower class of people he had opened a house on easier terms". ${ }^{29}$

In May 1762 he announced that he had been using a new method of inoculation for the last four months and that more than 200 patients had had less than 100 pustules each. ${ }^{30}$ Later he disclosed that his new method was performed without any incision and "that the most curious eye could not discern where the operation had been performed for the first 48 hours; and with this advantage, that he is always certain of determining whether the Patient receives the infection or not". 365 persons had been inoculated since the beginning of the year and not one had been confined in bed for longer than two days. ${ }^{31}$ He now had "a new medicine that will very much reduce the fomes of this dreadful distemper". Either he or his son would attend

\footnotetext{
21 Ipswich Journal, 16 April, 14 and 21 May 1757.

22 Ibid., 1 October 1757.

23 Ibid., 8 April 1758.

24 Ibid., 28 October 1758.

${ }^{25}$ Ibid., 24 February 1759.

26 Ibid., 15 September 1759.

27 Ibid., 25 October 1760.

28 Ibid., 2 August 1760.

20 Ibid., 19 December 1761.

20 Ibid., 1 May 1762.

21 Ibid., 25 September 1762.
} 


\section{The Suttons and the business of inoculation}

patients within a distance of thirty or forty miles. Within a few months he had announced a new method of inoculation, a new specific medicine for the disease, and the fact that his son, presumably Robert $j r$., was now in practice with him.

Sutton continued to enlarge his claims in November 1762 when he announced: "Out of 453 patients by him inoculated since December last, not one has been confined in bed 2 days in any stage of the Disease. He thinks it highly necessary to acquaint the Public that he has lately found a specific for the smallpox which if exhibited some few days before the eruption (as well in the natural way as by inoculation) renders the Distemper very benign." 32 His son Robert had now opened two houses at Barrow near Bury St. Edmunds for inoculation. ${ }^{33}$ The following year Robert (sr.) wrote: "he had brought inoculation to its greatest perfection since by means of his specific he is able to communicate the distinct sort in as mild a degree as can be desired ... . his son has since the first of January inoculated between 500 and 600 , and not one has been confined in bed two days for it". ${ }^{34}$ Up to this time the Suttons had confined their work to Suffolk, but in 1763 they opened their first inoculation house in Norfolk. ${ }^{25}$

However, not everyone who was acquainted with Robert Sutton and his method of inoculation believed it to be harmless, since the Parish Meeting of Debenham threatened to prosecute anyone performing inoculations in their parish. ${ }^{30}$

\section{DANIEL SUTTON}

Robert Sutton's second son Daniel (baptized May 1735)37 joined his father in practice, either in the last few months of 1762 or early in 1763. Daniel's career up to this time is difficult to trace. No surgeon had paid tax on the premium for his apprenticeship, but he could have been apprenticed to his father without paying a premium. Daniel later claimed that he had had extensive practice with his father, but he also wrote that he had been assistant to a surgeon in Essex from 1760 to $1763 .^{38}$ Moore, who published his book ${ }^{39}$ while Daniel Sutton was still alive, wrote that Daniel had been assistant to a Mr. Bumstead in Oxford.

Daniel did not stay long in Suffolk, but moved to Ingatestone, Essex, on the main London to Harwich road, during 1763. There is a tradition that the move was prompted by a quarrel between Daniel and his father. ${ }^{40}$ At first Daniel met with local opposition at Ingatestone. ${ }^{\mathbf{1 1 . 4 2}}$ However, in 1764 smallpox broke out at Maldon where a subscription was raised for Daniel to inoculate the whole village; as a result he inoculated seventy of the gentlemen and tradesmen, and 417 of the poor. None

32 Ibid., 27 November 1762.

23 Ibid.

« Ibid., 28 May 1763.

${ }^{25}$ Ibid.

ac Ibid., 18 June 1763.

${ }^{37}$ Kenton Parish Register, op. cit., note 14 above.

s8 D. Sutton, The inoculator or Suttonian system of inoculation, fully set forth in a plain and familiar manner, London, 1796.

20 J. Moore, The history of the smallpox, London, Longman, etc., 1815.

${ }^{10}$ Abraham, op. cit., note 3 above.

41 Ipswich Journal, 19 November 1763.

42 Ibid., 3 December 1763. 


\section{David Van Zwanenberg}

of the patients died, and three weeks later there were no further cases of smallpox..$^{43}$ This seems to have established him, because when an attempt was made to prosecute him for spreading disease in 1765, the Grand Jury threw out the bill.4.45

In May 1766 Daniel Sutton built a chapel for his patients and he employed the Rev. Robert Houlton M.A., at a salary of $\mathbf{2 0 0}$ guineas a year, to officiate. Houlton not only preached in praise of the Suttonian System of inoculation, but he also had the sermon prir ted and distributed.46

News of Daniel's success had reached Europe, and in June he was visited by Mr. Ristch, first surgeon to the King of Poland, who was said to have been surprised at the slightness of the operation.47 By October 1766, Daniel had opened another establishment in Kent, and within a few months claimed that he and his assistant, Mr. Peale, had inoculated 2000 people there with complete success. ${ }^{48}$ By 1768 , Houlton could announce that surgeons throughout the country and at certain selected cities overseas had contracted to practise only the Suttonian System of inoculation. ${ }^{90}$ Daniel himself had inoculated 723 persons in the course of twenty weeks in $1765,{ }^{50}$ and in the course of five years inoculated more than 20,000 people at Ingatestone. ${ }^{51}$

By this time the name of Sutton was well known throughout the country. In a report of a fatal case of inoculation in the Gentleman's Magazine it was specifically mentioned that the medicines given were supposed not to be Mr. Sutton's. ${ }^{52}$ Early in 1768, Mr. Row wrote to the Gentleman's Magazine praising the "amazing success" of the Suttons and suggesting that the government should buy their secrets and make them generally available. ${ }^{53}$ More members of the Sutton family were now involved in the inoculating business. ${ }^{54}$ Robert (sr.) had bought the Hall at Framingham Earl in Norfolk and practised from there. Daniel had moved to London and, with the assistance of his younger brother William (baptized 1740), ${ }^{55}$ was working from a house near Hyde Park. Robert ( $j r$.) was in Paris, although he had returned to Suffolk by $1770 ;^{56}$ Joseph (baptized 1742) ${ }^{57}$ was in Oxford; Thomas (baptized 1744) ${ }^{58}$ in the Isle of Wight; and James (baptized 1746) ${ }^{59}$ in Wakefield.

Enquiries concerning the Suttonian System from Vienna and Brussels prompted

* R. Houlton, Indisputable facts relative to the Suttonian art of inoculation, with observations on its discovery, progress, encouragement, opposition etc., Dublin, W. G. Jones, 1768.

4 Ibid.

is Chelmsford Chronicle, 17 May 1765.

* R. Houlton, A sermon on inoculation, 1766.

47 Ipswich Journal, 21 June 1766.

48 Ibid., 13 October 1766.

10 Houlton, op. cit., note 43 above.

so Chelmsford Chronicle, 17 May 1765.

${ }^{61}$ Houlton, op. cit., note 43 above.

s2 Gentleman's Mag., 1767, 37: 532.

ss Ibid., 1768, 38: 23.

ss Houlton, op. cit., note 43 above.

ss Kenton Parish Register, op. cit., note 14 above.

so Ipswich Journal, 21 April 1770.

67 Kenton Parish Register, op. cit., note 14 above.

68 Ibid.

so Ibid. 


\section{The Suttons and the business of inoculation}

an official reply from the Physicians and Surgeons to his Majesty the King. ${ }^{00}$ In their statement they admitted that the Suttons had had a great success with their method, but they pointed out that others had used a similar method successfully before the Suttons. They attributed the success of the Suttonian System to the rules that had been laid down regarding diet and exposure of the patients to cold air. Although it had been said that Sutton had inoculated 40,000 without loss, they thought that "he had not always been successful, though he failed so very seldom that they did not think it ought to be considered as an objection to the method." The statement in fact admitted that the Suttons had had considerable success, with a low mortality. However, as was pointed out by two correspondents, His Majesty's Physicians and Surgeons had appeared to praise the Suttons in one sentence and then tried to belittle them in the next. ${ }^{61}$

With such national publicity the Suttons no longer advertised so frequently in East Anglian newspapers although they continued their widespread campaign of inoculation in the 1770s and 1780s. The youngest son, Henry (baptized 1751), ${ }^{62}$ left his father's home at Framingham Earl to open his own inoculation house at Bedingfield in Suffolk during 1777. ${ }^{\text {os }}$

Robert Sutton (sr.) died in April 1788, and at that time his six sons were continuing their inoculation practices. One was still in Suffolk, two were in London, one in Oxford, another in Paris, and the last in Bordeaux. ${ }^{\text {t4 }}$ Presumably Joseph was one of the brothers practising in France, since in 1774 he had offered to treat Louis XV, who was dying of smallpox. ${ }^{65}$ In 1796 Daniel published his account of the Suttonian System ${ }^{68}$ in which he claimed that he had introduced the new system of inoculation in 1763. He gave no credit to the part that his father had played, which may be some confirmation of the quarrel between them. No references have been discovered for any of Daniel's brothers after this date. Daniel himself did not die until 1819.67

\section{THE SUTTONIAN SYSTEM}

After his eldest son had severe smallpox following inoculation, Robert Sutton had tried to improve the technique of the actual inoculation. ${ }^{88} \mathrm{He}$ seems to have discovered that there were fewer complications if the inoculum was applied with the minimum of trauma. In his new method, announced in 1762, he made it clear that there was no incision and that the site could not be discovered for forty-eight hours; furthermore a lesion would only be visible after that if the inoculation had "Taken". 89 This could only have been achieved if the technique involved a form of pressure in which the instrument was held tangentially to the skin. There is some confirmation

\footnotetext{
*o Gentleman's Mag., 1768, 38: 75.

-1 Ibid., pp. 215 and 216.

-2 Kenton Parish Register, op. cit., note 14 above.

Ipswich Journal, 25 January 1777.

* Ibid., 19 April 1788.

os Abraham, op. cit., note 3 above.

* Sutton, op. cit., note 38 above.

-7 Gentleman's Mag., 1819, 89: 281.

-8 Houlton, op. cit., note 43 above.

co Ipswich Journal, 25 September 1762.
} 


\section{David Van Zwanenberg}

of this in Daniel Sutton's book in which he wrote that "the charged lancet is held slantwise to $1 / 16$ " deep in the skin." 70 There is fortunately a detailed eye-witness account of Daniel Sutton inoculating a small boy, Bamber Gascoyne, in 1766. "Mrs. Wallis was the infected person, she had about seven pustules with large white heads on them. The doctor thrust a lancet in one of them which he immediately applied to the arm of Bamber and put so small a part of the point under the skin that he was not sensible of the points touching him. Then he put on his cloathes without plaister, rag or any covering whatever ...". ${ }^{11}$ This confirms that the inoculum was applied with minimal trauma, since a small boy was unaware of it.

The Suttonian System included a special regimen both before and after the actual operation. The patient had to abstain from all animal food and alcoholic liquor for two weeks before inoculation. Afterwards he had to take exercise in the open air until such time as he developed a fever, which was then treated with cold water, warm tea, and thin gruel by mouth. Once the eruption appeared the patient was persuaded to get up and walk about the garden, regular purges were given and the secret remedy was used to try and control the symptoms. ${ }^{72,78}$ The secret remedy was never divulged publicly but Bamber Gascoyne's father was convinced that it contained mercury, since "the patient is affected with white or sore gums, his teeth loose and his breath tainted". ${ }^{74}$ According to Creighton, the remedy contained antimony in addition to the mercury. ${ }^{75}$

\section{OTHER INOCULATORS}

The Suttons made inoculation popular, both by their apparent success and by their advertisements, so it is not surprising that their methods were soon copied. From 1760 onwards the newspapers of East Anglia carried an increasing number of advertisements of surgeons practising inoculation; this reached a peak in the first four months of 1767 when no fewer than twenty-three surgeons advertised in the Ipswich Journal. ${ }^{76}$ Such advertisements continued to appear until the end of the century.

Thomas Dimsdale (1712-1800) was the other famous eighteenth-century inoculator. He published an account of his method of inoculation in $1767,,^{77}$ and in November 1768 successfully inoculated the Empress of Russia, ${ }^{78}$ for which he received the rank of Baron, $£ 10,000$ in cash, and a pension of $£ 500$ per year. ${ }^{79}$ There was a family tradition that Dimsdale learned his method of inoculation from the Suttons; ${ }^{80}$

${ }^{70}$ Sutton, op. cit., note 38 above.

71 Strutt Papers: letters of B. Gascoyne, M.P., to John Strutt of Terling Place. Original letters in Terling Place; typescript copy in the Essex Record Office, Chelmsford.

${ }^{23}$ Sutton, op. cit., note 38 above.

73 Houlton, op. cit., note 43 above.

74 Strutt Papers, op. cit., note 71 above.

75 C. Creighton, $A$ history of epidemics in Britain 1666-1893, 2 vols., Cambridge University Press, 1891-94, p. 609.

20 Ipswich Journal, 1767. (Published every Saturday.)

72 T. Dimsdale, On the present method of inoculation for the smallpox, London, 1767.

78 Gentleman's Mag., 1768, 38 : 586.

70 W. J. Bishop, 'Thomas Dimsdale, M.D., F.R.S. (1712-1800), and the inoculation of Catherine the Great of Russia', Ann. med. Hist., 1932, New Series, 4: 321-338.

so Abraham, op. cit., note 3 above. 


\section{The Suttons and the business of inoculation}

however, Dimsdale claimed in $1767^{81}$ that he had been inoculating regularly for "upwards of 20 years". If true, this would mean that his career as an inoculator started some years before Robert Sutton's (sr.). Dimsdale's original technique was quite different to the Sutton method, since he had used a thread, first drawn through a pustule of the donor, and then plastered into an incision on the patient's arm. In his book in 1767, Dimsdale described another method in which a small incision was made through the "scarf skin" for "not more than $\frac{1}{8}$ ". This little wound was stretched between the finger and thumb so that the edges of it could be moistened with the variolous matter. Dimsdale makes it clear that he had altered his technique because of the success of the method practised in other parts of the country, although at no time does he mention the Suttons by name. It is clear that he had modified his technique towards a less traumatic method but it is also obvious that he did not go as far as Sutton had done in inoculating without any incision at all. Houlton claimed that Dimsdale had altered his technique after talking to some of Sutton's patients and that he never personally witnessed Sutton's method. ${ }^{82}$ In spite of Dimsdale's success with the inoculation of the Russian Empress and his later involvement in a "pamphlet war" with Dr. J. C. Lettsom, ${ }^{83}$ the technique which achieved fame in England was the Suttonian System. In 1808, when Parliament debated the merits of vaccination versus inoculation, Jenner's method was compared with "the old or Suttonian Method".84

\section{FINANCIAL ASPECTS}

Inoculation was practised extensively by surgeons in the second half of the eighteenth century, probably because it was a paying proposition. The Suttons charged between $£ 33 \mathrm{~s}$. $0 \mathrm{~d}$. and $£ 77 \mathrm{~s}$. $0 \mathrm{~d}$. for inpatients; the money had to be paid before the inoculation and the price included all board and lodging for three or four weeks, except tea and wine. On occasions the Suttons advertised that they would inoculate the poor gratis on the recommendation of parish officers, ${ }^{85}$ but they were not always so generous. Robert ( $j r$.) offered to inoculate people in their own homes: "if within 20 miles and not less than 10 persons", the charge was $£ 11 \mathrm{~s}$. $0 \mathrm{~d}$. per person, if more than thirty persons then it was 10s. $6 \mathrm{~d}$. each, and for the benefit of towns where the parishioners approved of the inoculation of the poor, provided there were not less than 100 patients the cost was $5 \mathrm{~s} .3 \mathrm{~d}$. each. ${ }^{86}$

High prices were sometimes charged to the gentry, as is shown in the private accounts of Richard Hoare of Boreham, Essex, who paid Mr. Sutton $£ 20$ for inoculation in May 1769, and also paid Baron Dimsdale $£ 25$ in 1775 for inoculating his children. ${ }^{87}$ The cost of inoculation was felt also by those who were responsible for managing Houses of Industry. In 1771 it was calculated that the annual cost of guarding against smallpox by inoculation at the Nacton House of Industry in Suffolk

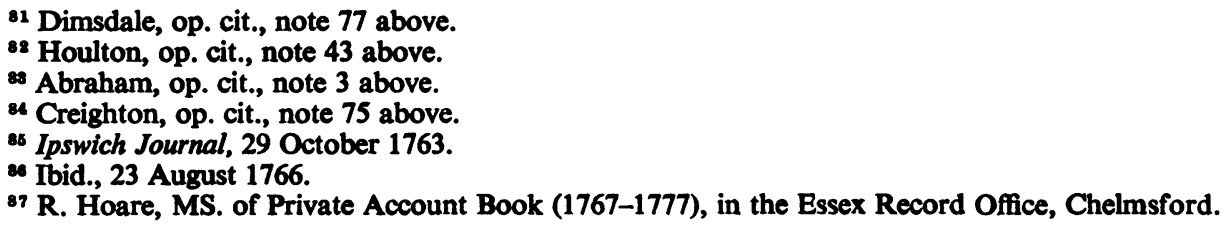




\section{David Van Zwanenberg}

was $\mathrm{f40}$, which was equal to the surgeon's total annual salary for all other services. ${ }^{88}$ In 1793 the Feoffees of Beccles provided $£ 15$ 10s. Od. towards the cost of inoculating the poor of the parish. ${ }^{89}$

It seems quite credible therefore that Daniel Sutton made 2000 guineas in 1764 and this increased to 6000 guineas in $1766 .{ }^{20}$ It is not surprising that he could afford to enter his son Daniel for Trinity Hall, Cambridge, in 1786,91 and when he died in $\mathbf{1 8 1 9}$ he left a considerable fortune, which his family subsequently squandered. ${ }^{92}$

\section{THE VALUE OF INOCULATION}

As a prophylactic method inoculation for smallpox presented a paradox, since it did cause the disease that it claimed to prevent. Its use, therefore could only be justified on two grounds: first, for the individual, if inoculation caused a form of smallpox that was distinctly milder than the natural variety; second, for communities, if it could be used for aborting epidemics of natural smallpox or if by producing a reasonably high level of immunity in the local population it could reduce the chances of further outbreaks of the disease.

The inoculators all claimed that they caused smallpox in a mild form. The Suttons claimed a very low mortality indeed (Daniel-only five deaths after 40,000 inoculations), and none of their contemporaries or their critics since that time has ever produced any evidence to show that they exaggerated. Even the Royal Physicians and Surgeons admitted that the Suttons' mortality was low, although possibly not as low as they claimed. Evidence has been found of a few deaths from inoculated smallpox in Suffolk, but none of these deaths was caused by the Suttons themselves or by anyone claiming to use their method.98.94 From the individual's point of view, therefore, there was definitely some value in being inoculated by the Suttons.

As regards communities, there were definite occasions when inoculation was used systematically to abort natural epidemics. In addition to the occasion at Maldon already mentioned, one occurred at Diss in 1784 when 1,100 of the population were inoculated without loss, ${ }^{96}$ and another at Hadleigh in $1778 .{ }^{96}$ It has also been claimed that the mass inoculation of the population of Maidstone by Daniel Sutton in 1766 reduced the incidence of smallpox there for the rest of the century. ${ }^{97}$ Many other

${ }^{88}$ D. Warsop, 'Social aspects of Nacton Workhouse in its early years', Suffolk Review, 1973, 4: no. 2.

${ }^{\circ}$ E. A. Goodwyn, A century of a Suffolk town. Beccles 1760-1860, Ipswich, 1968, part 1, pp. 53-54.

${ }^{20}$ Houlton, op. cit., note 43 above.

$91 \mathrm{~J}$. Venn and J. A. Venn, Alumni Cantabrigienses from the earliest times to 1900, Cambridge University Press, 1922-1954.

"2 E. E. Wilde, Ingatestone and the Essex Great Road, London, Oxford University Press, 1913, chapters 18 and 19.

*3 W. Goodwin, MS. of journal (1785), in the East Suffolk Record Office, Ipswich. Records two deaths from inoculation.

" R. Langslow, The case of Master Day of Yoxford-with comments on the late trial between $R$. Langslow M.D. and Mr. Bobbitt, Bungay, 1800. Records two deaths from inoculation in Suffolk in the 1790 s.

${ }^{\circ}$ Ipswich Journal, 2 June 1784.

" Ibid., 20 June 1778.

27 P. E. Razzell, 'Edward Jenner: the history of a medical myth', Med. Hist., 1965, 9: 216-229; quoting J. Howlett, Observations on the increased population of Maidstone, 1782. 


\section{The Suttons and the business of inoculation}

examples of this method throughout the country have been quoted by Razzell.98 It became apparent that smallpox caused by inoculation was just as infectious as the natural variety, so that most of the inoculators chose isolated houses in which to practise, and they were often forbidden to bring their patients into towns or villages.99

The increase in population in the late eighteenth century has been attributed to the success of inoculation, ${ }^{100}$ and the same writer has claimed that the successes of vaccination were often due to the early vaccinators using variolous material in mistake for the true vaccine of cowpox. ${ }^{101}$ Unfortunately no evidence of the morbidity or mortality from smallpox in East Anglia in the late eighteenth century has been found. The editor of the Ipswich Journal published the total deaths and deaths due to smallpox until 1757, but, having made a number of admitted mistakes, abandoned the idea. The present author can therefore produce no evidence to show that inoculation caused the population to increase or that it conferred any other benefit on the population as a whole.

\section{THE REPUTATION OF THE SUTTONS}

Daniel Sutton died in 1819 in his eighty-fourth year. His obituary in the Gentleman's Magazine included the following: ". . . The benefits which the world has derived from Mr. Sutton's practice have been duly appreciated and will cause his name and memory to be recollected with respect and distinction."102 Despite this eulogy, the Suttons have not enjoyed a "favourable press". Even while Daniel was still alive, he had been criticized for unfair advertising. using secret remedies, and discovering nothing new $;^{103}$ and since that time the Suttons have been called unqualified practitioners, ${ }^{104,105}$ quacks, ${ }^{106,107}$ and "not medical men". ${ }^{108}$ Although the Sutton method of inoculation was a household name for many years, and Daniel wrote a book about it, no member of the family is mentioned in the Dictionary of national biography. ${ }^{100}$

Robert Sutton (sr.) was certainly trained as a surgeon in the recognized manner of his day; he was licensed to practise as such, and in fact worked as a surgeon for some years before he started to inoculate. His sons may have been apprenticed to him, although there is no evidence on this point. Daniel appears to have worked as an assistant to a recognized surgeon. Their contribution to medical practice was that they found a technique of inoculating smallpox which had a low mortality rate, and

'8 P. E. Razzell, 'Population change in eighteenth-century England. A reinterpretation', Econ. Hist. Rev., 1965, 18: 312-332.

'9 Ipswich Journal, 26 September 1772 refers to Ipswich; 7 November 1772 refers to Hadleigh; 15 May 1779 refers to Sudbury.

100 Razzell, op. cit., note 98 above.

${ }^{101}$ Razzell, op. cit., note 97 above.

102 Gentleman's Mag., 1819, 89: 281.

103 Moore, op. cit., note 39 above.

104 A. S. MacNalty, 'The prevention of smallpox from Edward Jenner to Monckton Copeman', Med. Hist., 1965, 9: 1 .

${ }^{105}$ The history of inoculation and vaccination for the prevention and treatment of disease, XVIIth International Congress of Medicine, London, 1913.

${ }^{106}$ E. J. Edwardes, $A$ concise history of smallpox and vaccination in Europe, London, Lewis, 1902.

$107 \mathrm{~W}$. White, The history of a great delusion, London, E. W. Allen, 1885.

${ }^{108}$ S. M. Copeman, 'Milroy Lectures', Lancet, 1898, i: 121.

${ }^{109}$ Abraham, op. cit., note 3 above; Dixon, op. cit., note 4 above. 


\section{David Van Zwanenberg}

on occasions they used this technique systematically to abort local epidemics. However, there can be little doubt that they exploited this technique to make money. Daniel in particular employed the Reverend Houlton to act as an advertising agent. They also introduced a complicated regimen of diet, exercise, purges, and secret remedies. They may have believed this regimen to be essential for success, but since it almost certainly did nothing to improve their results, many commentators have believed that their whole method contained nothing of value. It is possible that the Suttons realized that their results were good because of their inoculating technique, and not due to the regimen. In that case their efforts to disguise the useful parts of the Suttonian Method from their competitors may also have hidden the value of the method from later commentators.

The inoculators ran two particular risks: first, they could cause severe smallpox in the patient; and second, they could start an epidemic because the patient actually suffered from smallpox and was therefore infectious. The Suttons seem to have avoided the first by their inoculating technique and the second by either isolating their patients in inoculation houses or by inoculating all the members of a community at one time. On the evidence available, therefore, it is likely that the Suttons did more good than harm.

Controversy concerning inoculation has continued intermittently since the beginning of the nineteenth century, and has recently been revived by the writings of Razzell, who believes that the original decline in the prevalence of smallpox was due to the work of the inoculators. Even if they failed in their attempts to reduce the scourge of smallpox, the inoculators deserve some credit in a historical context because they were the first people to try and reduce the incidence of an infectious disease by raising the immunity of the population; and also because their technique of applying material from a pustule to an area of trauma on the skin was "borrowed" by Jenner for his vaccinations. It could be claimed that the technique adopted by the World Health Organisation to eradicate smallpox, in which punctures are made with a bifurcated needle on as small an area of skin as possible, ${ }^{110}$ owes more to the Suttonian Method than it does to Jenner.

\section{ACKNOWLEDGEMENTS}

My thanks are due to the Hon. C. R. Strutt for allowing me to quote from the Strutt Papers; to Mrs. I. Hewitt, Librarian of the Ipswich Hospital Library; to the Archivist and staff of the East Suffolk, West Suffolk, Norfolk and Essex Record Offices for all their assistance in tracing references; to J. Dickson F.R.C.S., for reading and commenting on the paper; to Dr. G. D. Duncan, the Regional Medical Officer, and the East Anglian Regional Health Authority for allowing me the time to do the research; to Mr. Dove, Ipswich Hospital Photographer, for preparing the map, and to my secretary Miss J. Ridout.

${ }^{110}$ A. S. Benenson, International symposium on smallpox vaccine, Bilthoven, Symposium Series Immunobiology Standard Vol. 19, 1972, pp. 17-22. 